\title{
Using Space-borne Hyperspectral Imagery on Mapping Nitrogen Fertilizer Excess to the Environment
}

\author{
Yehia H. Miky ${ }^{1}$, Ahmed F. El Shouny ${ }^{2}$ \\ ${ }^{1}$ King Abdel Aziz University, Faculty of environmental Designs, Jeddah, Saudi Arabia, \\ Assistant Professor, Faculty of Engineering, Aswan University, Egypt \\ ${ }^{2}$ King Abdel Aziz University, Faculty of environmental Designs, Jeddah, Saudi Arabia, \\ Assistant Professor, Survey Research Institute, National Water Research Center, Egypt,
}

\begin{abstract}
Nowadays, Farmers tend to apply high rates of fertilizers such as Nitrogen $(N)$ in order to get a high yield. But the challenge is how to optimize nitrogen $(N)$ management to ensure high yield production while improving $N$ use efficiency and protecting the environment. The calculation of $N$ nutrition index (NNI) requires destructive sampling and chemical analysis to determine biomass and plant $N$ concentration, which is time and cost consuming and, thus, impractical for in-season site-specific $N$ management across large areas. The objective of this study was to evaluate the potential of using space-borne hyperspectral remote sensing imagery to track excessive fertilization areas to protect environment from Nitrogen excess. The study site is located at At Tawdihiyah farm, which was conducted on a 50 ha sandy loam soil in the Eastern Province of Saudi Arabia. To study the Effect of Nitrogen Fertilizer on the Environment of At Tawdihiyah region, four sets of Hyperspectral Imagery (EO-1 Path/Row: 165/43) were chosen to represent the four seasons. Narrowband greenness VIs were computed. Biomass and Plant $N$ concentration the results indicated that, all VIs used were significantly correlated with the $N$ concentration among all seasons. However the proposed technique have been used to conduct precise Nitrogen content, it is also needs a ground based validation under different on-farm conditions using different types of satellite data.
\end{abstract}

Keywords: hyperspectral imagery, nitrogen concentration, nitrogen nutrition index; EO-1

\section{Introduction}

Farming in the Arab East is a perpetual contest between man and nature. On most of the Arabian Peninsula, one of the most arid regions on earth, rainfall is scant, and much of it runs off into the desert sands or quickly evaporates. Yet in Saudi Arabia, the largest and driest country on the Peninsula, current agricultural advances are among the most innovative and most dramatic in the Arab world.

Since the 1950s, the application of plant nutrients, including Nitrogen fertilizers, has increased substantially to increase crop production and land reclamation. Nowadays, agricultural chemical fertilizers, including $\mathrm{N}$ fertilizers, are an essential component of the agricultural activities that help to increase crop production and to improve the properties of the nutrient-deficient lands.

Farmers tend to apply high rates of fertilizers such as Nitrogen $(\mathrm{N})$ in order to get a high yield. Nitrogen is an important element in chlorophyll constitution. Its supply rate affects biomass production and yield to a large extent. The world nitrogen fertilizer demand is expected to increase from a total of 105.3 million tonnes in 2011 to 112.9 million tonnes in 2015 at the annual growth of 1.7 percent. Of the overall increase in demand for 7.6 million tonnes nitrogen, 68 percent would be in Asia, 18 percent in America, 10 percent in Europe, 3 percent in Africa and 1 percent in Oceania. [8] However, a possible negative effect of The over-application of $\mathrm{N}$ fertilizer is the risks of environmental pollution due to $\mathrm{N}$ loss into the groundwater or atmosphere, increased nitrate content in the groundwater and greenhouse gas emissions. Precision $\mathrm{N}$ management strategies are developed to improve fertilizer $\mathrm{N}$ use efficiency by matching the fertilizer $\mathrm{N}$ input to crop $\mathrm{N}$ demand in proper time and space [11].

To avoid such an excessive fertilization, one of the most important steps at European level was the Nitrate Directive (91/676/EEC) in 1991 concerning the protection of ground and surface waters against pollution caused by nitrates $\left(\mathrm{NO}^{3-}\right)$ from agricultural sources. This directive imposed the identification of waters containing more than $50 \mathrm{mg} \mathrm{L}^{-1}$ of $\mathrm{NO}^{3-}$ (or that could contain this concentration if no action is taken to reverse the trend), and the adoption of action programmes on these vulnerable areas [6]. Plant $\mathrm{N}$ concentration (PNC) and uptake (PNU) have been commonly used as crop $\mathrm{N}$ status indicators. To improve crop $\mathrm{N}$ status diagnosis, the concept of critical $\mathrm{N}$ concentration $(\mathrm{Nc})$ has been proposed as the minimum PNC necessary to achieve maximum aboveground biomass production [17]. Nc decreases with increasing biomass. Their relationship can be described using a negative power function, called the critical $\mathrm{N}$ dilution curve [21].

Thus, the Nc at any given biomass value can be calculated by this dilution curve. The actual PNC $(\mathrm{Na})$ can then be compared to $\mathrm{Nc}$, and their ratio is termed the $\mathrm{N}$ nutrition index (NNI).

NNI is a better indicator for diagnosing crop $\mathrm{N}$ status than $\mathrm{PNC}$ or PNU [21]. If $\mathrm{Na}$ is greater than $\mathrm{Nc}(\mathrm{NNI}>1)$, this indicates an over-supply of $\mathrm{N}$, while the opposite is true if $\mathrm{Na}$ is smaller than $\mathrm{Nc}(\mathrm{NNI}<1)$ [21]. An NNI value of one

\section{Volume 4 Issue 11, November 2015}




\section{International Journal of Science and Research (IJSR) \\ ISSN (Online): 2319-7064 \\ Index Copernicus Value (2013): 6.14 | Impact Factor (2014): 5.611}

indicates an optimal $\mathrm{N}$ supply. The calculation of NNI requires destructive sampling and chemical analysis to determine biomass and plant $\mathrm{N}$ concentration, which is time and cost consuming and, thus, impractical for in-season sitespecific $\mathrm{N}$ management across large areas. The estimation of the NNI based on spectral data has been proven feasible using field spectrometers operated on the ground [27] or mounted on tractors [17]. However the possibility to detect the $\mathrm{N}$ status using remotely rather than proximal sensed information has still to be tested [20]. Several studies demonstrated that leaf chlorophyll concentration can be estimated through hyperspectral vegetation indices based on the visible and red edge (680-760 nm) spectral domains [8]. Hyperspectral sensors are characterized by a high number of narrow and contiguous acquisition bands that allow a better description of specific portions of the electromagnetic spectrum compared to broadband sensors and, thus, better performances in biochemical parameter estimation [24].

The correlation between leaf pigments and leaf $\mathrm{N}$ incorporated in chlorophyll molecular structure [13], [14] justified the use of vegetation indices for the determination of plant $\mathrm{N}$ condition [21]. Moreover, hyperspectral data have been also successfully used to estimate aboveground biomass accumulation, the second input required for NNI computation, using combinations of visible and near infrared reflectance in the form of simple or normalized ratios [20].

Satellite remote sensing approach can achieve comparable performance as ground-based active canopy sensors for estimating rice $\mathrm{N}$ status and is applicable to other rice planting regions. It is more efficient for large area applications, but is more influenced by weather conditions, while active canopy sensors are independent of environmental light conditions. It requires special training to process satellite remote sensing data, while active canopy sensors are easy to use, but are not suitable for large area applications [22].

The main objective of this study was to evaluate the potential of using space-borne hyperspectral remote sensing imagery to track excessive fertilization areas.

\section{Materials and Methods}

\subsection{Research Area}

The study site is located at AtTawdihiyah farm, which was conducted on a 50 ha sandy loam soil in the Eastern Province of Saudi Arabia within the latitudes of $24^{\circ} 10^{\prime} 22.7^{\prime \prime}$ and $24^{\circ}$ $12^{\prime} 37.2^{\prime \prime} \mathrm{N}$ and longitudes of $47^{\circ} 56^{\prime} 14.6^{\prime \prime}$ and $48^{\circ} 05^{\prime}$ 08.56" E (Figure 1) The field was under center pivot irrigation system and has been under continuous wheat cultivation. The choice of this site was due to the availability of hyperspectral imagery for all seasons along year 2015.

\subsection{Data used}

Image data were acquired using the Hyperion hyperspectral sensor on NASA's Earth Observer-1 (EO-1) platform. The sensor spans the spectral range from 356-2577 nm with a bandwidth of $\sim 10 \mathrm{~nm}$ leading to a total of 242 bands, acquired at $30 \mathrm{~m}$ spatial resolution, and a swath width of 7.65 $\mathrm{km}$ from a $705 \mathrm{~km}$ altitude with an approximate 50:1 signalto-noise ratio (SNR). The acquired Hyperion image was downloaded in Level 1T from the United States Geological Survey (USGS) website [25]. Radiometric and geometric corrections were required so that reflectance spectra could be derived from the data and then related to a specified crust property. The size of the sub-scene used in this research (region of interest) covers an area of $6.45 \mathrm{~km}$ (215 samples) by $6.30 \mathrm{~km}$ (210 lines).

To study the Effect of Nitrogen Fertilizer on the Environment of AtTawdihiyah region, four sets of Hyperspectral Imagery (EO-1 Path/Row: 165/43) were chosen to represent the four seasons as shown in Table 1.

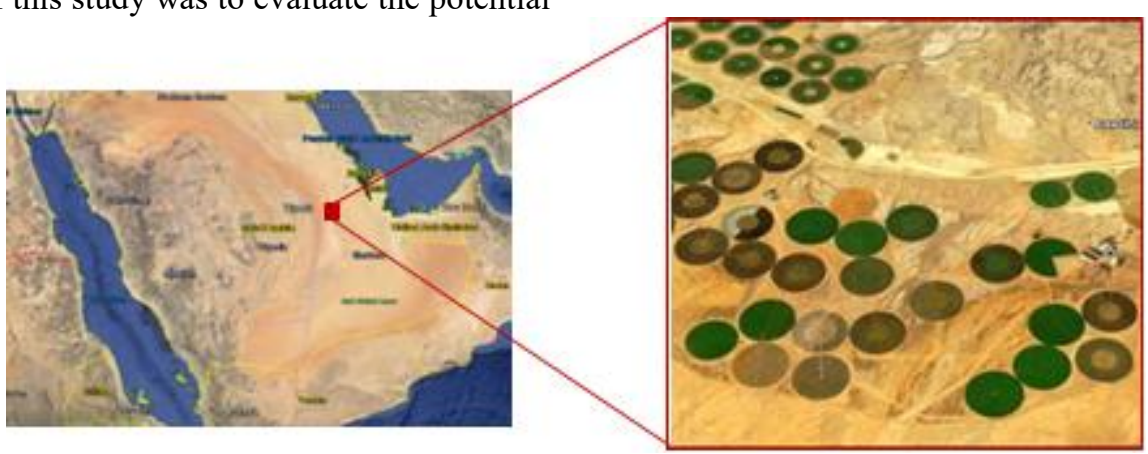

Figure: 1. Study site, AtTawdihiyah, Saudi Arabia.

Table 1: Data acquired for AtTawdihiyah region during four seasons.

\begin{tabular}{|c|c|c|c|c|}
\hline \multirow{2}{*}{ Seasons } & scene & Acquisition date & Sun_Azimuth angle & $\begin{array}{c}\text { Sun_Elevation } \\
\text { angle }\end{array}$ \\
\hline \multirow{2}{*}{ Autumn } & EO1H1650432014337110K0_1T & 3 December 2014 & 141.995001 & 33.351466 \\
& EO1H1650432015280110K0_1T & 7 October 2015 & 121.637798 & 40.984466 \\
\hline \multirow{2}{*}{ Winter } & EO1H1650432015015110K0_1T & 15 January 2015 & 136.335786 & 30.508917 \\
& EO1H1650432015058110K1_1T & 27 February 2015 & 123.071425 & 37.379787 \\
\hline \multirow{2}{*}{ Spring } & EO1H1650432015106110K2_1T & 16 April 2015 & 100.183325 & 44.642611 \\
& EO1H1650432015150110K0_1T & 30 May 2015 & 85.8783240 & 54.038213 \\
\hline \multirow{2}{*}{ Summer } & EO1H1650432015196110K0_1T & 15 July 2015 & 85.057594 & 50.900184 \\
& EO1H1650432015234110K2_1T & 22 Augusts 2015 & 99.454628 & 48.320511 \\
\hline
\end{tabular}

Volume 4 Issue 11, November 2015 


\section{International Journal of Science and Research (IJSR) \\ ISSN (Online): 2319-7064}

Index Copernicus Value (2013): 6.14 | Impact Factor (2014): 5.611

\subsection{Image Data Pre-Processing}

Exclusion of bad bands (not calibrated, redundant, noise from atmospheric water vapor, low signal to noise ratio) left 158 bands for the analysis. [19]. these are bands 8-57 (427$925 \mathrm{~nm}), 79-119$ (933-1336 nm), 133-164 (1477-1790 nm), 183-184 (1982-1992 nm) and 188-220 (2032-2355 nm). Hyperion includes digital number to radiance transformation, radiance to reflectance conversion and atmospheric corrections /reflectance retrieval.

\subsubsection{DN To Radiance Conversion}

EO1-Hyperion hyperspectral image consists of number of continuous spectral bands, each pixel of which stored the energy as a digital number (DN). Stacked image is used to convert DN into Radiance values. The digital numbers were stored as 16-bit signed integer. Image was converted into absolute radiance by using following equation. Each band of NIR (1 to 70) and SWIR (71 to 242) was divided by its scale factor i.e 40 and 80 respectively [24]. The image is stored in ENVI Standard format and then it is converted in BIL (Bit in Line) data format.

\subsubsection{Atmospheric Corrections}

Removing the influence of the atmosphere is a critical preprocessing step in analyzing images of surface reflectance. Properties such as the amount of water vapor, distribution of aerosols, and scene visibility must be known. Because direct measurements of these atmospheric properties are rarely available, they must be inferred from the image pixels. All images were recalculated to at-sensor radiance with subsequent atmospheric correction using Atmospheric Analysis of Spectral Hypercubes (FLAASH®) model.

\subsection{Methodology}

The critical $N$ concentration of wheat was described using Equation (1) [4] The NNI can be calculated using Equation (2) $[15]$.

$$
\begin{aligned}
& N_{c}=4.34 W^{-0.41} \\
& N N I=\frac{N_{\text {act }}}{N_{c}}
\end{aligned}
$$

In Equations (1) and (2), $\mathrm{W}$ is the above ground dry biomass in $\mathrm{Mg} \cdot \mathrm{ha}-1, \mathrm{Nc}$ is the plant critical $\mathrm{N}$ concentration expressed as a percentage of the dry matter, and Nact is the actual plant $\mathrm{N}$ concentration expressed as a percent of the dry matter.

The recommended equations to estimate biomass for shrubs and small tree species Equation (3) [1] were used to estimate the biomass of Above Ground Biomass (AGB) in the study area.

$$
A G B=9.17+3.000 \mathrm{Ln}(\mathrm{NDVI})
$$

The effect of Nitrogen fertilizer on the environment will take place if the nutrition index (NNI) is greater than one (NNI > 1) i.e. $\quad N_{a c t}>N_{c}$, this indicates an oversupply of Nitrogen fertilizer.
In this study Narrowband greenness vegetation indices and $\mathrm{N}$-related spectral indices are used to estimate Wheat above ground dry biomass and actual plant $N$ concentration.

\subsubsection{Spectral Indices}

Narrowband greenness VIs are combinations of reflectance measurements sensitive to the combined effects of foliage chlorophyll concentration, canopy leaf area, foliage clumping, and canopy architecture. Similar to the broadband greenness VIs, narrowband greenness VIs are designed to provide a measure of the overall amount and quality of photosynthetic material in vegetation, which is essential for understanding the state of vegetation. Narrowband greenness VIs are intended for use with imaging spectrometers.

Most of these VIs use reflectance measurements in the red and near-infrared regions to sample the red edge portion of the reflectance curve. The red edge is a name used to describe the steeply sloped region of the vegetation reflectance curve between $690 \mathrm{~nm}$ and $740 \mathrm{~nm}$ that is caused by the transition from chlorophyll absorption and nearinfrared leaf scattering. Use of near-infrared measurements, with much greater penetration depth through the canopy than red measurements, allows estimation of the total amount of green material in the column.

Making narrowband measurements in the red edge allows these indices to be more sensitive to smaller changes in vegetation health than the broadband greenness VIs, particularly in conditions of dense vegetation where the broadband measures can saturate.

Spectral indices considered to be good candidates for estimating plant $\mathrm{N}$ concentration were tested. Included were indices specifically aimed at $\mathrm{N}$ estimation $[\mathrm{N}$ content and $\mathrm{N}$ concentration] as well as some indices aimed at chlorophyll estimation [chlorophyll content and chlorophyll concentration. (Table 2)

\section{Results and Discussion}

Using Space-borne Hyperspectral Imagery to estimate NNI for diagnosing high rates of Nitrogen fertilizer was the main objective of this study. Because water absorption obscures $\mathrm{N}$ absorption features in the shortwave bands, it is difficult to detect plant $\mathrm{N}$ concentrations from $\mathrm{N}$ absorption features in this portion of the electromagnetic spectrum [3]. Thus, it is appropriate to use reflectance in the visible and red-edge bands to estimate $\mathrm{N}$ concentrations based on the good relationships between chlorophyll concentrations and plant $\mathrm{N}$ concentrations. In addition, biomass has a good relationship with the NDVI in green vegetation, and the NNI can be calculated using the $\mathrm{N}$ concentration, biomass and a known critical $\mathrm{N}$ curve.

While we want to diagnose the areas of Nitrogen excess, which means NNI greater than one, we can calculate Biomass using NDVI for all seasons and then $\mathrm{N}_{\mathrm{c}}$ can be estimated. If $\mathrm{N}_{\text {act }}$ just greater than $\mathrm{N}_{\mathrm{c}}$ means Nitrogen excess. 


\section{International Journal of Science and Research (IJSR) \\ ISSN (Online): 2319-7064}

Index Copernicus Value (2013): 6.14 | Impact Factor (2014): 5.611

The results indicated that all of Vegetation Indices MCARI, MTVI2, RVI I , RVI II and Viopt have significant positive correlations with Biomass and Nitrogen concentration, correlation matrix shown in Table 3.
For all seasons studied, Biomass, chlorophyll concentration and $\mathrm{N}$ content were estimated. Table 4 shows a descriptive statistics of Wheat Biomass, chlorophyll and $\mathrm{N}$ content for all seasons studied over AtTawdihiyah, Saudi Arabia.

Table 2: Narrowband greenness vegetation indices

\begin{tabular}{|c|c|}
\hline $\begin{array}{l}\text { Modified Chlorophyll Absorption Ratio Index (MCARI) } \\
M C A R I=\left[\left(\rho_{700}-\rho_{670}\right)-0.2\left(\rho_{700}-\rho_{550}\right)\right] *\left(\rho_{700} / \rho_{670}\right)\end{array}$ & [8] \\
\hline $\begin{array}{l}\text { Modified Chlorophyll Absorption Ratio Index - Improved (MCARI2) } \\
\text { MCARI2 }=\frac{1.5\left[2.5\left(\rho_{800}-\rho_{670}\right)-1.3\left(\rho_{800}-\rho_{550}\right)\right]}{\sqrt{\left(2 * \rho_{800}+1\right)^{2}}-\left(6 * \rho_{900}-5 * \sqrt{\rho_{670}}\right)-0.5}\end{array}$ & [13] \\
\hline $\begin{array}{l}\text { Modified Red Edge Normalized Difference Vegetation Index (MRENDVI) } \\
\text { MRENDVI }=\frac{\rho_{750}-\rho_{705}}{\rho_{750}+\rho_{705}-2 * \rho_{445}}\end{array}$ & [23], [7] \\
\hline $\begin{array}{l}\text { Modified Red Edge Simple Ratio (MRESR) } \\
\text { MRESR }=\frac{\rho_{750}-\rho_{445}}{\rho_{705}-\rho_{445}}\end{array}$ & {$[23],[7]$} \\
\hline $\begin{array}{l}\text { Modified Triangular Vegetation Index }(\text { MTVI }) \\
M T V I=1.2\left[1.2\left(\rho_{800}-\rho_{550}\right)-2.5\left(\rho_{670}-\rho_{550}\right)\right]\end{array}$ & [13] \\
\hline $\begin{array}{l}\text { Modified Triangular Vegetation Index - Improved (MTVI2) } \\
M T V I 2=\frac{\left.1.541 .2\left(\rho_{800}-\rho_{550}\right)-2.5\left(\rho_{670}-\rho_{550}\right)\right\rfloor}{\sqrt{\left(2 * \rho_{800}+1\right)^{2}}-\left(6 * \rho_{800}-5 * \sqrt{\rho_{670}}\right)-0.5}\end{array}$ & [13] \\
\hline $\begin{array}{l}\text { Red Edge Normalized Difference Vegetation Index (RENDVI) } \\
R E N D V I=\frac{\rho_{750}-\rho_{705}}{\rho_{705}+\rho_{705}}\end{array}$ & [11] \\
\hline $\begin{array}{l}\text { Red Edge Position Index (REPI) } \\
R E P I=700+40 *\left(\frac{\left(\left(\rho_{670}+\rho_{780}\right) / 2\right)-\rho_{700}}{\rho_{740}-\rho_{700}}\right)\end{array}$ & [7] \\
\hline $\begin{array}{l}\text { Transformed Chlorophyll Absorption Reflectance Index (TCARI) } \\
T C A R I=3\left[\left(\rho_{700}-\rho_{670}\right)-0.2\left(\rho_{700}-\rho_{550}\right)\left(\frac{\rho_{700}}{\rho_{670}}\right)\right]\end{array}$ & [13] \\
\hline $\begin{array}{l}\text { Triangular Vegetation Index }(\text { TVI }) \\
T V I=0.5\left[120\left(\rho_{750}-\rho_{550}\right)-200\left(\rho_{670}-\rho_{550}\right)\right]\end{array}$ & [2] \\
\hline $\begin{array}{l}\text { Vogelmann Red Edge Index } 1(\text { VREI1) } \\
\text { VREI1 }=\frac{\rho_{740}}{\rho_{720}}\end{array}$ & [26] \\
\hline $\begin{array}{l}\text { Vogelmann Red Edge Index } 2(\text { VREI2) } \\
\text { VREI2 }=\frac{\rho_{7 a 4}-\rho_{747}}{\rho_{715}+\rho_{726}}\end{array}$ & {$[26]$} \\
\hline
\end{tabular}

Table 3: Correlation matrix among Biomass, N concentration and chlorophyll indices

\begin{tabular}{|c|c|c|c|c|c|c|}
\hline & BIOMASS & MCARI & MTVI2 & RVI I & RVI II & Viopt \\
\hline BIOMASS & 1.00 & & & & & \\
\hline MCARI & 0.93 & 1.00 & & & & \\
\hline MTVI2 & 0.94 & 0.91 & 1.00 & & & \\
\hline NDVI & 0.96 & 0.92 & 0.99 & 1.00 & & \\
\hline RVI I & 0.81 & 0.76 & 0.93 & 0.91 & 1.00 & \\
\hline VIopt & 0.96 & 0.94 & 0.98 & 0.98 & 0.88 & 1.00 \\
\hline
\end{tabular}




\section{International Journal of Science and Research (IJSR) ISSN (Online): 2319-7064 \\ Index Copernicus Value (2013): 6.14 | Impact Factor (2014): 5.611}

Table 4: Descriptive statistics of Wheat Biomass, chlorophyll and N content for all seasons studied over AtTawdihiyah, Saudi Arabia.

\begin{tabular}{|c|c|c|c|c|}
\hline & Minimum & Maximum & Mean & SD \\
\hline \multicolumn{5}{|l|}{3 December 2014} \\
\hline Biomass $\left(\mathrm{t} \cdot \mathrm{ha}^{-1}\right)$ & - & 8.93 & 3.07 & 2.81 \\
\hline NDVI & 0.01 & 0.94 & 0.22 & 0.28 \\
\hline Plant $\mathrm{N}$ content $\left(\mathrm{kg} \cdot \mathrm{ha}^{-1}\right)$ & 1.77 & 64.56 & 3.32 & 1.36 \\
\hline \multicolumn{5}{|l|}{7 October 2015} \\
\hline Biomass $\left(\mathrm{t} \cdot \mathrm{ha}^{-1}\right)$ & - & 8.21 & 1.68 & 2.38 \\
\hline NDVI & 0.01 & 0.73 & 0.13 & 0.17 \\
\hline Plant $\mathrm{N}$ content $\left(\mathrm{kg} \cdot \mathrm{ha}^{-1}\right)$ & 1.83 & 143.35 & 4.00 & 1.94 \\
\hline \multicolumn{5}{|l|}{15 January 2015} \\
\hline $\operatorname{Biomass}\left(\mathrm{t} \cdot \mathrm{ha}^{-1}\right)$ & - & 8.19 & 2.29 & 2.53 \\
\hline NDVI & 0.02 & 0.74 & 0.16 & 0.19 \\
\hline Plant $\mathrm{N}$ content $\left(\mathrm{kg} \cdot \mathrm{ha}^{-1}\right)$ & 1.83 & 23.63 & 3.64 & 1.37 \\
\hline \multicolumn{5}{|l|}{27 February 2015} \\
\hline Biomass $\left(\mathrm{t} \cdot \mathrm{ha}^{-1}\right)$ & - & 8.81 & 2.39 & 2.63 \\
\hline NDVI & 0.01 & 0.89 & 0.26 & 0.23 \\
\hline Plant $\mathrm{N}$ content $\left(\mathrm{kg} \cdot \mathrm{ha}^{-1}\right)$ & 1.78 & 80.80 & 3.73 & 1.49 \\
\hline \multicolumn{5}{|l|}{16 April 2015} \\
\hline Biomass $\left(\mathrm{t} \cdot \mathrm{ha}^{-1}\right)$ & - & 8.22 & 1.91 & 2.62 \\
\hline NDVI & 0.01 & 0.73 & 0.15 & 0.18 \\
\hline Plant $\mathrm{N}$ content $\left(\mathrm{kg} \cdot \mathrm{ha}^{-1}\right)$ & 1.83 & 18.61 & 3.88 & 1.75 \\
\hline \multicolumn{5}{|l|}{30 May 2015} \\
\hline Biomass $\left(\mathrm{t} \cdot \mathrm{ha}^{-1}\right)$ & - & 8.14 & 2.77 & 2.52 \\
\hline NDVI & 0.03 & 0.71 & 0.18 & 0.21 \\
\hline Plant $\mathrm{N}$ content $\left(\mathrm{kg} \cdot \mathrm{ha}^{-1}\right)$ & 1.84 & 24.89 & 3.44 & 1.29 \\
\hline \multicolumn{5}{|l|}{15 July 2015} \\
\hline Biomass $\left(\mathrm{t} \cdot \mathrm{ha}^{-1}\right)$ & - & 7.25 & 1.76 & 1.84 \\
\hline NDVI & 0.02 & 0.53 & 0.11 & 0.09 \\
\hline Plant $\mathrm{N}$ content $\left(\mathrm{kg} \cdot \mathrm{ha}^{-1}\right)$ & 1.93 & 149.44 & 4.02 & 1.74 \\
\hline \multicolumn{5}{|l|}{22 Augusts 2015} \\
\hline Biomass $\left(\mathrm{t} \cdot \mathrm{ha}^{-1}\right)$ & - & 8.20 & 1.65 & 1.84 \\
\hline NDVI & 0.01 & 0.74 & 0.11 & 0.12 \\
\hline Plant $\mathrm{N}$ content $\left(\mathrm{kg} \cdot \mathrm{ha}^{-1}\right)$ & 1.83 & 135.58 & 3.25 & 2.27 \\
\hline
\end{tabular}

In summary, the proposed satellite remote sensing approach of using hyperspectral images, with low spatial resolution, to map the areas of excess Nitrogen fertilizer is more efficient for large area applications. However the proposed technique has been used to conduct precise Nitrogen content, it is also needs a ground based validation.

\section{Conclusions}

This study evaluated the potential of using Earth Observer-1 (EO-1) to map the areas of excess Nitrogen fertilizer across one year over AtTawdihiyah, Saudi Arabia. Based on the data used and results, one can conclude, Spectral indices are considered as good candidates for estimating the plant $\mathrm{N}$ concentration and biomass; all VIs used were significantly correlated with the $\mathrm{N}$ concentration among all seasons. However, more studies are needed to further evaluate and improve the proposed method of in-season Nitrogen content estimation and its effect on the under different on-farm conditions using different types of satellite data.

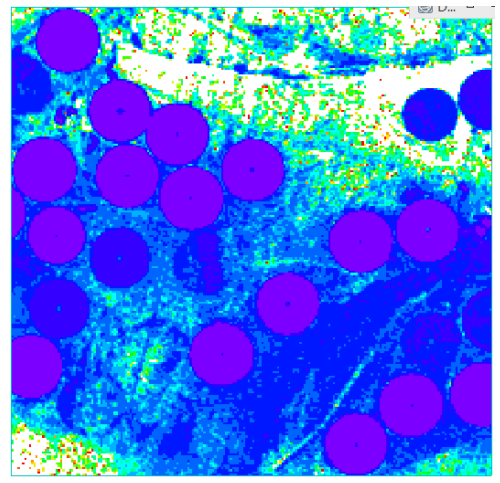

15 January 2015

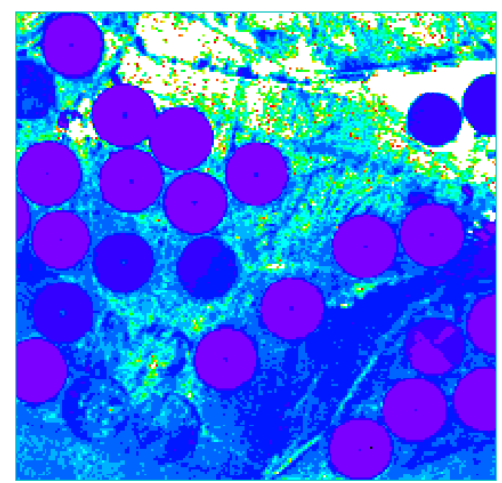

27 February 2015

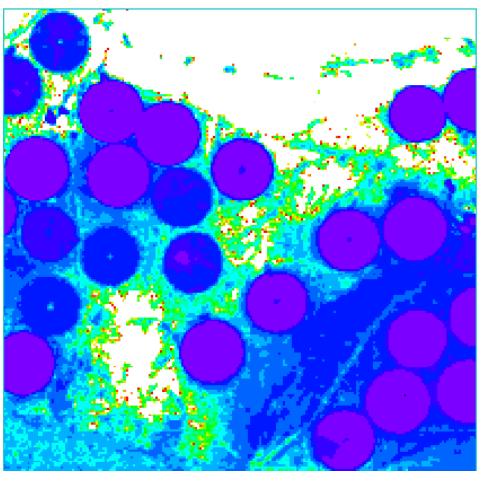

16 April 2015

Volume 4 Issue 11, November 2015 www.ijsr.net 


\section{International Journal of Science and Research (IJSR)}

ISSN (Online): 2319-7064

Index Copernicus Value (2013): 6.14 | Impact Factor (2014): 5.611

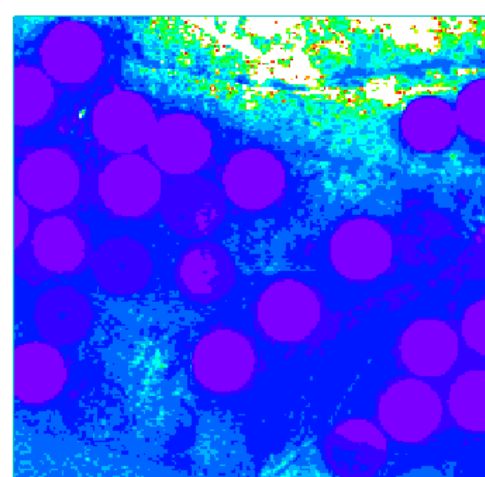

30 May 2015

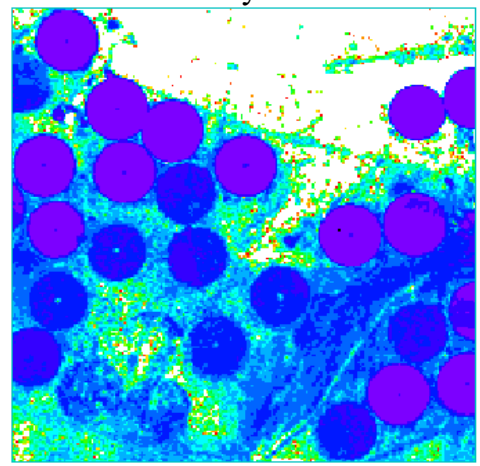

7 October 2015

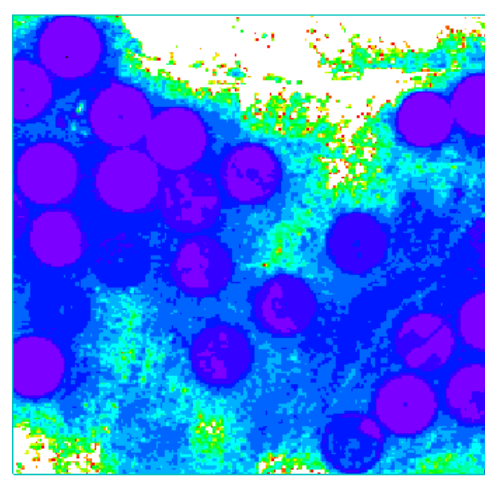

15 July 2015

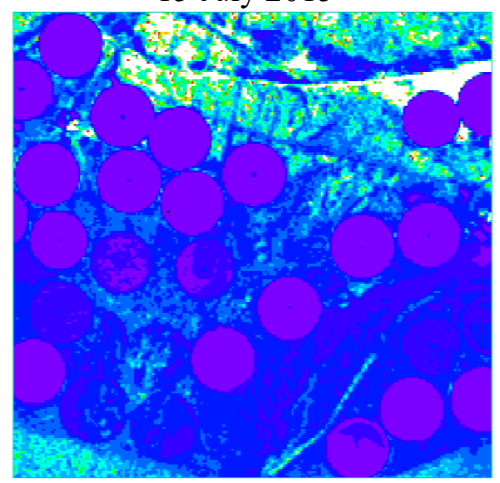

3 December 2014

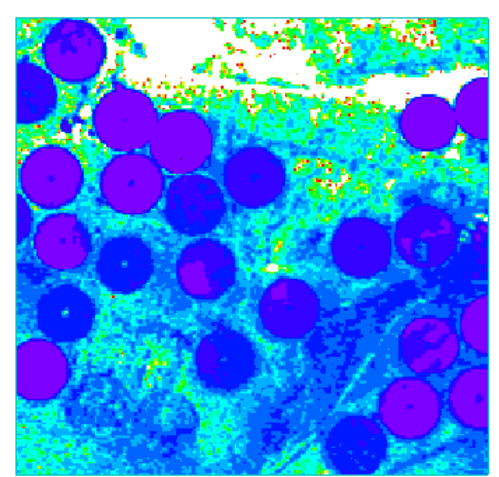

15 July 2015

\section{Nitrogen content}

$<5.0 \mathrm{~kg} \cdot \mathrm{ha}^{-1}$

$5.0-10.0 \mathrm{~kg} \cdot \mathrm{ha}^{-1}$

$>10.0 \mathrm{~kg} \cdot \mathrm{ha}^{-1}$

Figure 2: Nitrogen excess distribution over AtTawdihiyah, Saudi Arabia, for all seasons studied.

\section{References}

[1] Aranha, J.T., Viana, H.F. and Rodrigues, R., (2008). Vegetation classification by satellite image processing, A case study in North Portugal. International Conference and Exhibition on Bioenergy, International Conference and Exhibition on Bioenergy, April 6th - 9th 2008, Universidade do Minho, Guimarães, Portugal.

[2] Broge, N., and E. Leblanc. "Comparing Prediction Power and Stability of Broadband and Hyperspectral Vegetation Indices for Estimation of Green Leaf Area and Canopy Chlorophyll Density." Remote Sensing of Environment 76 (2000): 156-172.

[3] Chen, P.; Haboudane, D.; Tremblay, N.; Wang, J.; Vigneault, P.; Li, B. New spectral indicator assessing the efficiency of crop nitrogen treatment in corn and wheat. Remote Sens. Environ. 2010,114, 1987-1997.

[4] Chen, P.; Zhu, Y. A new method for winter wheat critical nitrogen curve determination. Agron. J. 2013, 105, 1839-1836.

[5] Chiara Cilia; Cinzia Panigada; Micol Rossini; Michele Meroni; Lorenzo Busetto;Stefano Amaducci; Mirco Boschetti; Valentina Picchi and Roberto Colombo. Nitrogen Status Assessment for Variable Rate Fertilization in Maize through Hyperspectral Imagery. Remote Sens. 2014, 6, 6549-6565.

[6] Clevers, J. G. P. W. 1994. Imaging spectrometry in agriculture-Plant vitality and yield indicators. Eurocourses:Remote Sensing 4: 193-219.

[7] Datt, B. "A New Reflectance Index for Remote Sensing of Chlorophyll Content in Higher Plants: Tests Using Eucalyptus Leaves." Journal of Plant Physiology 154 (1999): 30-36.
[8] Daughtry, C.S.T.; Walthall, C.L.; Kim, M.S.; de Colstoun, E.B.; McMurtrey, J.E. Estimating corn leaf chlorophyll concentration from leaf and canopy reflectance. Remote Sens. Environ. 2000, 74, 229-239.

[9] Doberman, A.; Witt, C.; Dawe, D.; Abdulrachman, S.; Gines, H.C.; Nagarajan, R.; Satawathananont, S.; Son, T.T.; Tan, P.S.; Wang, G.H.; et al. Site-specific nutrient management for intensive rice cropping systems in Asia. Field Crops Res. 2002, 74, 37-66.

[10] Evans, J.R. Photosynthesis and nitrogen relationships in leaves of C3 plants. Oecologia 1989, 78, 9-19.

[11] Gitelson, A., and M. Merzlyak. "Spectral Reflectance Changes Associated with Autumn Senescence of Aesculus Hippocastanum L. and Acer Platanoides L. Leaves." Journal of Plant Physiology 143 (1994): 286 292.

[12] Greenwood, D.J.; Gastal, F.; Lemaire, G.; Draycott, A.; Millard, P.; Neeteson, J.J. Growth rate and \% N of field grown crops: Theory and experiments. Ann. Bot. 1991, 67, 181-190.

[13] Haboudane, D., et al. "Hyperspectral Vegetation Indices and Novel Algorithms for Predicting Green LAI of Crop Canopies: Modeling and Validation in the Context of Precision Agriculture." Remote Sensing of Environment 90 (2004): 337-352

[14]Houles, V.; Guerif, M.; Mary, B. Elaboration of a nitrogen nutrition indicator for winter wheat based on leaf area index and chlorophyll content for making nitrogen recommendations. Eur. J. Agron. 2007, 27, 111.

[15]Lemaire, G.; Jeuffroy, M.H.; Gastal, F. Diagnosis tool for plant and crop $\mathrm{N}$ status in vegetative stage: Theory 


\section{International Journal of Science and Research (IJSR) \\ ISSN (Online): 2319-7064}

Index Copernicus Value (2013): 6.14 | Impact Factor (2014): 5.611

and practices for crop $\mathrm{N}$ management. Eur. J. Agron. 2008, 28, 614-624.

[16] Lemaire, G.; Meynard, J.M. Use of the Nitrogen Nutrition Index for analysis of agronomical data. In Diagnosis on the Nitrogen Status in Crops; Lemaire, G., Ed.; Springer-Verlag: Heidelberg, Germany, 1997; pp. 45-55.

[17] Mistele, B.; Schmidhalter, U. Estimating the nitrogen nutrition index using spectral canopy reflectance measurements. Eur. J. Agron. 2008, 29, 184-190.

[18]NASA Sensors-Hyperion. Available online: http://eo1.usgs.gov/sensors/hyperion (accessed on 15 October 2015)

[19] Peña, M.A.; Brenning, A.; Sagredo, A. Constructing satellite-derived hyperspectral indices sensitive to canopy structure variables of a Cordilleran Cypress (Austrocedrus chilensis) forest. ISPRS J. Photogramm. Remote Sens. 2012, 74, 1-10.

[20] Psomas, A.; Kneubuhler, M.; Huber, S.; Itten, K.; Zimmermann, N.E. Hyperspectral remote sensing for estimating aboveground biomass and for exploring species richness patterns of grassland habitats. Int. J. Remote Sens. 2011, 32, 9007-9031.

[21] Schlemmer, M.; Gitelson, A.; Schepers, J.; Ferguson, R.; Peng, Y.; Shanahan, J.; Rundquist, D. Remote estimation of nitrogen and chlorophyll contents in maize at leaf and canopy levels.Int. J. Appl. Earth Obs. Geoinf. 2013, 25, 47-54.

[22] Shanyu Huang; Yuxin Miao; Guangming Zhao; Fei Yuan; Xiaobo Ma; Chuanxiang Tan; Weifeng Yu; Martin L. Gnyp; Victoria I.S. Lenz-Wiedemann; Uwe Rascher; and Georg Bareth. Satellite Remote SensingBased In-Season Diagnosis of Rice Nitrogen Status in Northeast China. Remote Sens. 2015, 7, 10646-10667.

[23] Sims, D. and J. Gamon. "Relationships Between Leaf Pigment Content and Spectral Reflectance Across a Wide Range of Species, Leaf Structures and Developmental Stages." Remote Sensing of Environment 81 (2002): 337-354.

[24] Thenkabail PS, Enclona EA, Ashton MS and Meer B Van Der, 2004a. Accuracy assessments of hyperspectral waveband performance for vegetation analysis applications. Rem Sens Envir 91(3-4), pp. 354-376.

[25] USGS Global Visualization Viewer. Available online: http://glovis.usgs.gov (accessed on 24 June 2014).

[26] Vogelmann, J., B. Rock, and D. Moss. "Red Edge Spectral Measurements from Sugar Maple Leaves." International Journal of Remote Sensing 14 (1993): 1563-1575.

[27] Vouillot, M.O.; Huet, P.; Boissard, P. Early detection of $\mathrm{N}$ deficiency in a wheat crop using physiological and radiometric methods. Agronomie 1998, 18, 117-130.

\section{Author Profile}

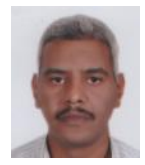

Yehia Hassan Miky, he received his bachelor degree in civil engineering with honor's degree in 1995, Minia University, Minia, Egypt. In 1997. In 2010 he awarded a doctoral degree in remote sensing by the Department of Photogrammetry and Remote Sensing, Siberian State Academy of Geodesy (SSAG), Russia. Tell 2014 he was the Head of Civil Engineering department, Faculty of
Engineering, Aswan University, Aswan. In 2015 he joined Department of Geomatics, Faculty of Environmental Design, King Abdul-Aziz University, Jeddah, Saudi Arabia

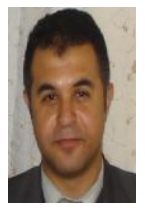

Ahmed Fouad El Shouny received his bachelor degree in civil engineering in 2004, Minufia University, minufia, Egypt. In 2008 he had received his Master degree, and while in 2011, he received his doctoral degree in surveying by the same university. He was the Head of department of Geodesy, survey Research Institute (SRI), National water research Center, Egypt until 2014. Then, he joined Department of Geomatics Faculty of Environmental Design, King Abdul-Aziz University, jeddah, Saudi Arabia 